\title{
Twelfth Century Literal Bible Commentaries: Comparing Jewish and Christian
}

\author{
Devorah Schoenfeld \\ Loyola University Chicago, dschoenfeld@luc.edu
}

Follow this and additional works at: https://ecommons.luc.edu/theology_facpubs

Part of the Biblical Studies Commons, Comparative Methodologies and Theories Commons, and the Religious Thought, Theology and Philosophy of Religion Commons

Author Manuscript

This is a pre-publication author manuscript of the final, published article.

\section{Recommended Citation}

Schoenfeld, Devorah. Twelfth Century Literal Bible Commentaries: Comparing Jewish and Christian. Religion Compass, 7, 12: 509-516, 2013. Retrieved from Loyola eCommons, Theology: Faculty Publications and Other Works, http://dx.doi.org/10.1111/rec3.12090

This Article is brought to you for free and open access by the Faculty Publications and Other Works by Department at Loyola eCommons. It has been accepted for inclusion in Theology: Faculty Publications and Other Works by an authorized administrator of Loyola eCommons. For more information, please contact ecommons@luc.edu. c) (†) $\ominus$

This work is licensed under a Creative Commons Attribution-Noncommercial-No Derivative Works 3.0 License. (C) John Wiley \& Sons Ltd 2013 


\title{
Twelfth Century Literal Bible Commentaries: Comparing Jewish and Christian
}

\author{
Devorah Schoenfeld* \\ Loyola University Chicago
}

\begin{abstract}
In the twelfth century, both Jewish and Christian Bible commentators began to emphasize literal, or historical, or contextual, approaches to interpreting scripture. These commentators wrote predominantly line-by-line commentaries that focused the reader's attention on linguistic questions in the biblical text. There was also a renewed interest in seeing the Bible in its own terms rather than exclusively through the lens of earlier midrashic or patristic commentaries, although those continued to play an important role. These developments happened at the same time for both Christian and Jewish scholars, who were often in conversation with each other about how to interpret the Bible.
\end{abstract}

In the twelfth century, both Jews and Christians began to read the Bible in new ways. While the older approach was characterized by lengthy discussions of themes, the new approach went line-by-line to eludicate the difficulties as they arise. The newer approach drew on older traditions - the rabbinic and patristic tradition, respectively-but also left room for innovation. Sometimes, this innovation was achieved by recombining pieces from patristic or midrashic texts, other times, it was based on reading the text strictly within the context of scripture - an approach that can be called literal, or contextual, or 'the plain sense'. The history of twelfth-century interpretation is the history of the development of this sense, in both Jewish and Christian exegesis. ${ }^{1}$

Jewish scholarship in France only began to flourish in the twelfth century. Although Jews had lived in France since at least Carolingian times, ${ }^{2}$ there is no record of Jewish scholarship in France before the eleventh century. ${ }^{3}$ Records of Northern French Jewish biblical interpretation are very sparse before the time of Rashi, with only fragmentary commentaries by Rabbi Menahem ben Helbo (1015-1085) to help bridge the gap between Sephardic Jewish learning and Jewish biblical interpretation in Northern France. (Grossman 2000, p. 326-8, 331).

In the twelfth century, medieval Latin Christian biblical exegesis in Northern Europe also underwent a renewal, with a new interest in line-by-line interpretation of the Bible. Biblical interpretation had flourished during the Carolingian period through the tenth century but there was little in the eleventh century. Beryl Smalley calls this time period a 'dramatic pause' in the history of biblical interpretation, and suggests that it was brought about by monastic reformers who emphasized prayer at the expense of Bible study (Smalley 1964, p.44-45). Smalley suggests that Fulbert of Chartres, based on his reputation as an educator, may have produced a Bible commentary that has been lost, but no writings of his on scripture have been preserved (Smalley 1964, p.47). 


\section{Rashi and the Glossa Ordinaria: A Turning Point in Exegesis}

In the beginning of the twelfth century, two major and influential Bible commentaries were completed: the Glossa Ordinaria (generally known as the Gloss) and the commentary of Rabbi Shlomo Yitzhaki (known by his initials as Rashi) on the Tanakh. Both were standard texts for Bible study for at least two centuries after their composition. The two commentaries are roughly contemporary and date from the late eleventh to early twelfth centuries: Rashi died in 1106, and while the earliest Gloss manuscripts date from between 1120 and $1140,{ }^{4}$ it seems to have had its origins with Anselm of Laon, who died in 1117.

The Gloss was the foundation of twelfth-century and thirteenth-century monastic and cathedral education and the basis for supercommentaries (commentaries on his commentary) through the end of the Middle Ages and was used as a standard Bible text from 1150 through the eighteenth century (Smalley 1984, p.455, Frohlich and Gibson, 1992, p.ix). Volumes of the Bible with the Gloss were more widely copied in the twelfth century than any other book, and it remained in use through the Reformation (De Hamel 1984, p.xiii). The Gloss covers the entire Bible, both Old and New Testaments. Like Rashi's commentary, the Gloss is constructed largely out of earlier exegesis. The Glossa Ordinaria is made up of two kinds of glosses: marginal and interlinear. Marginal glosses tend to be direct quotes or paraphrases from patristic or Carolingian exegesis, including Jerome, Bede, and Rabanus and Paschatus Radbertus, as are many interlinear comments (Gibson 1992, p.viii-x).

The Gloss did not present itself as anything new or different, and it has been described as 'a work of consolidation' and an anthology (Evans 1984, p.47, Swanson, 2001, p.166-7, Smalley 1989, p.46-66). But by its particular combination or marginal interlinear glosses, it builds something new out of the sources it cites. Gilbert Dahan has shown the importance and influence of the innovative technique of interlinear glossing and examined how the Gloss uses techniques associated with literal interpretation such as grammatical and textual analysis. In his discussion of literal techniques of analysis (such as systematic grammatical and linguistic analysis, rhetorical analysis, and the study of the style of each biblical book), he observes the Gloss practicing these techniques (Dahan 1999, p. 124-8, 100, 246-52).

The Gloss is not primarily a literal commentary. In its anthologizing of patristic and subsequent sources, it collected literal as well as non-literal comments. It does, however, often make clear distinctions between them, labeling its comments as literal, historical, anagogical, or tropological (Smith 2009, p.67). Further, the very layout of the Gloss focuses the attention of the reader on the meaning of individual words. The nature of the gloss as a composite commentary meant that the addition or subtraction of glosses in later manuscripts could change the nature of the story it tells. ${ }^{5}$

Written at around the same time as the Gloss, Rashi's commentary was the starting point for all subsequent European Jewish exegesis through the Enlightenment. It exists in more manuscripts than any other Jewish Bible commentary ${ }^{6}$ and was the first Hebrew book to be printed (Grossman 1995, p.213). His commentaries seem to have covered the entire Bible, although his commentaries on Ezra, Nehemiah, Chronicles, and the end of Job (from 40:25) have been lost. ${ }^{7}$ Rashi's commentary on the Bible shaped the subsequent history of twelfth-century Jewish biblical exegesis, to the point that for the rest of the century, almost all European Jewish biblical exegesis responded in some way to Rashi's commentary, and he influenced many Christian exegetes as well. Most of his comments quote or paraphrase midrashic or other Late Antique Jewish exegesis. Rashi, however, is not merely a compiler; he adapts his sources to promote his own exegetical agenda. The nature of this exegetical agenda is one of the major concerns of scholarship on Rashi's commentary. ${ }^{8}$ 
Rashi has been associated with the trend of literal exegesis since the Middle Ages. For the Christian thinkers Herbert of Bosham, Andrew of St. Victor, and Nicholas of Lyra, Rashi and his students were a source (and an authority) for the literal sense of scripture (Goodwin 2006, p.67-71, Berndt 2000, p.481, Halperin 1963, Klepper 2007). Jewish opinion was less uniform. Rashi's student and grandson Rashbam had a much more ambiguous opinion on the literality of his grandfather's exegesis: In his commentary on Genesis 37:1, Rashbam claims that Rashi had attempted to compose a peshat commentary but did not entirely succeed. Debates about the literality of Rashi's commentary continue in contemporary scholarship. Sarah Kamin points out that Rashi does not in fact use the term peshat, and that his peshuto shel mikra was different from what later commentators understood as peshat. Rather than analyzing biblical language, grammar, and syntax, literary composition and structure, as would be the case in a literal commentary, she suggests that Rashi's commentary was intended to integrate rabbinic expositions and narratives with the biblical text. (Kamin, 1986, p.16)

Whether or not Rashi's commentary was itself literal, it certainly functioned as a source of inspiration for later Jewish Northern French Jewish (and some Christian) exegetes in their investigation of the literal sense of scripture. The century following Rashi saw an explosion of Bible and Talmud study in Northern France. As an example of the breadth of exegetical creativity, Avraham Grossman mentions ten commentaries written during this century on the book of Job alone (Grossman, 2000, p.348). Major Bible commentators from this subsequent period included Rashbam (Rabbi Samuel ben Meir), Shemaiah, Joseph Kara, Eliezer of Beaugency, and Joseph ben Isaac Bekhor Shor. Of these, Joseph Kara, Shemaiah, and Rashi's grandson Rashbam explicitly wrote their commentaries as a response to Rashi's, and the others were also strongly influenced by his exegesis (Grossman 2000, p.323, 356, 359, 363). Rashi's students and descendants and their school, then, were responsible for much of twelfth-century exegesis. Rashi stood at the beginning of the expansion and development of Jewish biblical scholarship in France.

\section{Twelfth-Century Commentators: The Literal and Historical Sense}

The later twelfth century saw a substantive shift from commentaries like Rashi's and the Glossa Ordinatia that use midrashic and patristic commentaries alongside more innovative contextual or literal interpretations to commentaries like that of Rashbam and Andrew of St. Victor that separate the literal, contextual, or historical sense from other senses of scripture and comment on them separately. These exegetes did not see their historical or literal interpretation as the only possible interpretation of scripture, far from it, but they did see it as a way of reading the Bible that could stand on its own.

These twelfth-century commentators often build their commentaries around that of Rashi and the Glossa Ordinaria, taking them as starting points and developing their methods further. The Psalms commentary of Gilbert of Poitiers (1075-1154), known as the media glosatura because of its place between the Glossa Ordinaria and Peter Lombard, draws heavily on the Gloss with the addition of some theological excursions in which Gilbert reaches back to patristic sources. Gilbert's commentary sometimes appears as an expanded, developed version of the Glossa Ordinaria on Psalms, but as Theresa Gross-Diaz has shown, it is more likely that Gilbert was himself involved in a later stage of the development of the Gloss, and that therefore, some of the ideas in the Gloss originate with his commentary rather than vice versa (Gross-Diaz, 1996, p.122-148). Gilbert's main innovations were structural: He wrote his commentary in continuous paragraphs rather than as comments attached to the biblical text, and he wrote a prologue to the book introducing it from a literary perspective and describing its subject matter, method of proceeding, purpose, title, type of prophecy, name, number, and order, which is similar to how works of secular literature were introduced (Gross-Diaz, 1996, 76-79). 
Similarly, Rashbam, or Rabbi Samuel ben Meir (1085-1160), built his commentary on that of Rashi, as he explicitly states in his comments on Exodus 21:1. In his commentary on Genesis 37:2, he sets out his distinction between literal and non-literal senses of scripture. The non-literal level requires rabbinic exegesis, and it is this level which is legally binding. Literal exegesis, though, is not bound by the rules of rabbinic exegesis and may even conflict with Jewish law. For example, Exodus 13:9 states, 'It should be for you a sign on your hand'. The traditional exegesis of this verse is that it requires one to bind scriptural verses on one's hand as tefilin.' Rashbam writes, in his comments on that verse, 'According to the depth of its literal meaning it should be constantly for a reminder, as if it were written on your hand'. Rashbam interprets 'on your hands' as a metaphor for mindfulness. He is able to interpret against Jewish law because for him, the words of the Bible have two distinct senses: the literal and the midrashic. One is still obligated to wear tefilin, even if that is not the literal meaning of the verses that requires it.

Another innovation in the twelfth century approach to the literal sense was increased attention to the question of how the books were written. Rashbam's student Eliezer of Beaugency went farther than any of his predecessors in identifying the role of the human redactor in the composition of prophetic works. For example, in Eliezer's commentary on Ezekiel 1:1-4 identifies the narrator as the redactor who compiled Ezekiel's words. This is a radical departure from Rashi, who sees the narrator as Divine (Harris 2009, p.150).

For Hugh of St. Victor, a full understanding of the literal sense was an essential first step for every student. His educational program began with memorization, then the use of liberal arts to understand the historical sense, then allegorical and tropological readings based on the foundation the student has established by study of the historical sense (Harkins 2009). Hugh sets out his program in book 6 of his Didascalion: de studio legendi [Teaching: concerning the study of reading]. A student should first read the books richest in history, such as Genesis, Exodus, Joshua, the Gospels, and Acts, with an eye to history and geography. The student may then progress to the study of doctrine through books such as the Epistles and the Apocalypse, and finally proceed to the study of the foreshadowing of Christ in the Pentateuch, Isaiah, Ezekiel, Job, Song of Songs, and Psalms. Hugh's historical commentary, then, represents only his first step. He keeps his literal commentary free from allegorical interpretation because the two types of exegesis are appropriate for different kinds of students.

With Hugh of St. Victor, we see the beginning of another trend: increased attention to the historical sense or reading the Bible as history. For Hugh of St. Victor, the historical sense was not necessarily a record of actual history. Rather, it is the thing that the words are describing. This is important for Hugh because it is this thing, that is described by the words, that itself signifies Christ. Historia, for Hugh, was an investigation into the things that the words on the text were describing, which was necessary prior to discovering their role in salvation history (Coulter 2010, p.108-109). Hugh's student Richard of St. Victor (d. 1173) demonstrated this more abstract idea of the historical sense in his use of mathematical analysis to explain the measurements of Ezekiel's Temple in his literal commentary on the vision in Ezekiel 40 (In visionem Ezechielis). This commentary, which in its manuscript form included illustrations, uses geometry to make mathematical sense of the Temple that Ezekiel saw in a vision (Cahn 1994, p.55-56).

Best known for his 'Sentences', Peter Lombard also wrote commentaries on the letters of Paul that were primarily focused on setting them in their historical context (Colish 1992a). Paul's historical context, and the differences between Paul's historical moment and Peter Lombard's own, even affected how Paul's moral teachings were to be understood. For example, he writes that Paul opposed marriage largely because he believed that the Second Coming was near. Therefore, today, when it is clear that life is going on, Peter argues in his commentary on 1 Corinthians that we should consider marriage the normal state of life. Similarly, he saw Paul's 
injunctions on women in 1 Corinthians and 1 Timothy to remain silent in Church as responding to a particular historical situation and not as intended to give direction for the future (Colish 1992a). Peter Lombard's Psalms commentary became known as the Magna glossatura and was read along with the Glossa ordinaria and Gilbert of Poitiers's Glossa media in schools, where it became one of their most studied texts. It draws heavily on the Glossa ordinaria but supplements it with lengthy prefaces and discussions on theological topics. Lombard's primary goal is to use the Psalms as a theological resource, but along the way, he uses his prologues to grapple with historical and literary questions. In his introduction, he connects the various Psalms with events in the life of David in order to make sense of it as a unified book. He also raises textual questions, calling into questions some of Jerome's translations and the titles that he gives to various Psalms. Still, his interpretation of Psalms is primarily theological and Christological, and he will often interpret Psalms as referring not to the life of David but to the life of Christ (Colish 1992b, p.544-5).

\section{Hebraism and Polemic}

In the twelfth century, two contrasting trends emerged in the relationship between Jewish and Christian commentaries. In the later twelfth century, some Christian exegetes began to read Jewish exegesis, primarily from the school of Rashi. At the same time, some commentaries began to take more polemical approaches, emphasizing interpretations that more directly refuted the other religions's teachings.

Hugh's student Andrew of St. Victor (d. 1175) continued his emphasis on literal exegesis. The content of his commentary is taken in large part from the Glossa Ordinaria or from Jerome. ${ }^{10} \mathrm{He}$ omitted comments that he considered too allegorical, and reformatted Jerome to make clear what in the text Jerome was responding to with his comments (van Liere 2005, p.67). When Jerome did not explain a passage to Andrew's satisfaction, he turned to Jewish exegesis, and in particular to the Northern French Jewish school of biblical interpretation. Andrew's commentaries show influences from Rashi, Joseph Kara, Rashbam, and Eliezer of Beaugency (van Liere 2005 , p.68). He seemed to have learned about these ideas in conversation, rather than reading them in the original Hebrew, and he may not have read Hebrew at all (van Liere 2005, p.68). But his use of Jewish exegesis was innovative and original.

Michael Signer suggested that the Jewish influence on Andrew of St. Victor was less in content than in method. Andrew's idea of the literal sense, he suggests, is very close to the Jewish idea of pshat, in that it is the most simple, straightforward meaning (Signer, 1993). As Fran van Liere writes, "If Hugh meant by literal mainly "historical", Andrew replaced it with "textual"'(van Liere, 2005, p.74). There are also striking parallels between Hugh's approach to the importance of the literal sense as a basis for the other senses of scripture and Rashbam's statement that it is important to understand the literal meaning of the biblical text so that one can understand what the midrash does with it (Touitou, 2005, p.122).

Peter Comestor's Historia Scholastica, an abridgment of and commentary on the entire Bible, drew on patristic and medieval exegesis to retell the Bible as a continuous, readable story. ${ }^{11}$ He often incorporates comments that have parallels in midrashic or Jewish medieval texts. For example, he adapts from Rashi the idea that the tree of knowledge in the Garden of Eden was a fig tree. ${ }^{12}$ His sources for these ideas are most frequently either Josephus or Christian Hebraists such as Jerome or Andrew of St. Victor, but there is some material that he seems to have derived directly from conversations with Jewish scholars or converted Jews (Feldman 1993). Despite his use of Hebrew sources, Comestor's commentary introduced new and damaging anti-Jewish ideas into Christian exegesis. In his commentary on 2 Kings, he created a narrative in which the lost Ten Tribes of Israel were imprisoned by Alexander the Great in 
order to protect humanity from their extreme wickedness and were the Gog and Magog of apocalypric prophecy. (Gow, 1995, p. 37-44)

Rupert of Deutz's commentary was one of the most explicitly polemical. His commentary shows the workings of the Trinity through biblical history. God the Father was manifest in the seven days of creation, God the Son in the time after the fall and before the redemption, and the Holy Spirit after the incarnation. The rejection of the Jews is repeated often in Rupert's theological scheme, to the point that Van Engen describes it as a 'preoccupation'. (Van Engen, 1983, p. 242) In his commentaries on Genesis 8.26 and John 7:14, he describes Jews as enemies of the church and covered with blood from the death of Christ.

Jewish anti-Christian polemic in the twelfth century was predominantly concerned with refuting Christian readings of the Bible. Rashi wrote that one of his motivations for his Psalms commentary was to refute Christological interpretations. He does not explicitly refute Christian interpretations elsewhere in his commentary, and scholarly opinion is divided on if he does so by implication. (For the debate, see Cohen 2008). Later commentaries such as Rashbam and Bechor Shor explicitly refute Christian interpretations on the Pentateuch as well, for example, interpreting the word 'Shiloh' in Genesis 49:10 as the Davidic kingdom, in response to Christian exegesis that saw in it a reference to Christ.

Twelfth century French biblical interpretation was pivotal in shaping the way the Bible was read in subsequent generations. Both Christian and Jewish interpreters developed new literal, historical, and contextual approaches to the study of the Bible. This similarity did not always lead to increased tolerance, and at times, it went alongside an increase in polemic. It is possible that the shared language of the 'plain' sense of scripture made Jewish-Christian debate both more possible and more necessary. When Jews read the Torah which they can only interpret through the lens of the Midrash and Christians read the Old Testament they can only understand in light of the New Testament, Jews and Christians have no text in common and therefore nothing about which it is possible to debate. The new emphasis on reading scripture outside its traditional commentaries made interreligious conversation possible, but the nature of that conversation was not always kind.

\section{Short Biography}

Devorah Schoenfeld is Assistant Professor of Theology (Judaism) at Loyola University Chicago and has previously taught at St. Mary's College of Maryland at University of California, Davis and at the Conservative Yeshiva in Jerusalem. Her book Isaac on Jewish and Christian Altars (Fordham 2013) compares Rashi and the Glossa Ordinaria on the near sacrifice of Isaac.

\footnotetext{
Notes

*Correspondence address: Devorah Schoenfeld, Loyola University Chicago, Department of Theology, Crown Center for the Humanities, 1032 W. Sheridan Rd. Chicago, IL 60660, USA. E-mal: dschoenfeld@luc.edu.

${ }^{1}$ Jewish exegetes typically use the terms pshat or pshuto shel mikra. Pshat has been variously translated as literal, contextual, or 'the plain sense' and is distinguished in Jewish exegesis from midrash and midrashic interpretations. Pshuto shel Mikra, or 'the pshat of the Biblical text', is the phrase that Rashi uses to describe his method, Sarah Kamin's (1986) reading of the meaning of the roots (pst) and (drs) in rabbinic literature and in Rashi leads her to conclude that peshuto shel miqra refers to the contextual meaning rather than the literal meaning. Christian exegetes writing in Latin would use the terms sensus litteralis which they would distinguish from mystical or allegorical senses and later in the fourteenth century also from the 'carnal' sense that George of Sienna ascribed to Jewish exegesis (Klepper 2008).

${ }^{2}$ Evidence for this include the privileges and special court oath designed for Jews under Louis the Pious in the ninth century. (Benbassa 1999, p.8-9. See also Bachrach 1977, chapters V and VI).
} 
3 Rashi wrote of his teacher Rabbi Yitzchak son of Rabbi Yehuda and mentions that there were 'men of wisdom and [great] deeds' in the previous generation, but we do not know who these men are. (Grossman 1995, p.35).

4 Smith 141-145

5 See for example the third chapter of my book (Schoenfeld 2013) which shows how incorporation of Isidore's comments into the marginal Gloss on Genesis 22 made it a much more anti-Jewish interpretation. Similarly, LaVere (2009) has shown that the addition of new glosses on the Song of Songs made it much more strongly emphasize preaching.

6 Deborah Abecassis lists 38 manuscripts of Rashi's commentary on Genesis alone (Abecassis 1999, p.261-3).

7 The commentaries ascribed to him on these books are not his (Grossman 2000, p. 333).

8 For a survey of scholarship on Rashi, see Levy 1988. For a more recent bibliography, see Grossman 2006.

9 See, for example, the discussion in the Babylonian Talmud, Menahot 36b-37a, which derives specific laws of tefilin from this verse.

10 Frans van Liere has shown that his commentary on the Heptateuch and on Samuel and Kings was excerpted from the Glossa Ordinaria. (van Liere, 1995). His commentary on the prophets is largely based on Jerome excepted from the Glossa Ordinaria. See van Liere, 2005, p. 63.

11 For an overview of both Peter Comestor's influence and his sources, see Morey 1993.

12 This idea predates Rashi and is also found in the Babylonian Talmud, Tractate Sanhedrin, 70b.

\section{Works Cited}

Abecassis, D. (1999). Reconstructing Rashi's Commentary on Genesis from Citations in the Torah Commentaries of the Tosafot. Ph.D. diss., McGill University.

Bachrach, B (1977) Early Medieval Jewish Policy in Western Europe. Minneapolis: University of Minnesota Press.

Benbassa, E. (1999) The Jews of France: A History from Antiquity to the Present. Princeton: Princeton University Press.

Berndt, R. (2000). The School of St. Victor in Paris. In: Hebrew Bible/Old Testament V 1, Pt 2, From the Beginnings to the Middle Ages (until 1300). Maegne Saebo (ed.) Göttingen: Vandenhoeck \& Ruprecht, pp. 467-495.

Cahn, W. (1994). Architecture and Exegesis: Richard of St.-Victor's Ezekiel Commentary and its Illustrations. The Art Bulletin. Vol. 76, No. 1 (Mar., 1994), pp. 53-68.

Cohen, S. (2008). Does Rashi's Torah Commentary Respond to Christianity? A Comparison of Rashi With Rashbam and Bechor Shor In: H Najman and J Newman (eds.), The Idea of Biblical Interpretation: Essays in Honor of James L. Kugel. Leiden: Brill.

Colish, M. (1992a). Peter Lombard as an Exegete of St. Paul. In M Jordan and Jr., K Emery (eds.), Ad litteram: Authoritative Texts and Their Medieval Readers, pp. 71-92. South Bend, Ind.: University of Notre Dame Press.

Colish, M. (1992b) Psalterium Scholastocorum: Peter Lombard and the Emergence of Scholastic Psalms Exegesis. Speculum 67(3), pp. 531-548.

Coulter, D. (2010) Historia and Sensus Litteralis: An Investigation into the Approach to Literal Interpretation at the Twelfth-Century School of St. Victor. In F Harkins (ed.), Transforming Relations: Essays on Jews and Christians Throughout History in Honor of Michael Signer, pp. 101-124. Notre Dame, IN: University of Notre Dame Press.

Dahan, G. (1999) L'exégése Chrétienne de la Bible en occident médiéval. Paris: Cerf, Paris.

Damian, Peter. (1989, 1900, 1992) Letters. 3 vols., Owen J. Blum (ed.) Washington DC: Catholic University of America Q5 Press.

De Hamel, C. (1984) Glossed Books of the Bible and the Origins of the Paris Booktrade. Suffolk: Brewer.

Evans, G.R. (1984) The Language and Logic of the Bible: The Earlier Middle Ages. Cambridge: Cambridge University Press, Cambridge.

Evans, G.R. (2001) Berengar of Tours, Roscelin and Peter Damian, The Medieval Theologians. G.R. Evans (ed.), pp. 85-93. Q6 Malden, MA: Blackwell Publishing.

Feldman, L. (1993) The Jewish Sources of Peter Comestor's Commentary on Genesis in His Historica Scholastica, In: D Koch and H Lichtenberger eds., Begegnungen zwischen Christentum und Judentum in Antike und Mittelalter, pp. 93-121. Göttingen: Vandenhoeck \& Ruprecht.

Frohlich, K and Gibson, M. (1992) Biblia latina cum Glossa ordinaria, Turnhout: Brepols.

Goodwin, D. (2006). Take Hold of the Robe of a Jew: Herbert of Bosham's Christian Hebraism. Leiden: Brill.

Gow, A. (1995) The Red Jews: Antisemitism in the Apocalyptic Age 1200 - 1600. Leiden: Brill.

Gross-Diaz, T. (1996). The Psalms Commentary of Gilbert of Poitiers. Leiden: Brill.

Grossman, A. (1995). The Early Sages of France [Hebrew]. Jerusalem: Magnes Press.

Grossman, A. (2000) The School of Literal Jewish Exegesis in Northern France. In: Hebrew Bible/Old Testament V 1, Pt 2, From the Beginnings to the Middle Ages (until 1300). Maegne Saebo (ed.), pp.321-371. Göttingen: Vandenhoeck \& Ruprecht.

Grossman, A. (2006). Rashi [Hebrew]. Jerusalem: Merkaz Zalman Shazar. 


\section{Devorah Schoenfeld}

Hailperin, H. (1963) Rashi and the Christian Scholars, Pittsburgh: University of Pittsburgh Press.

Harkins, F. (2009) Reading and the Work of Restoration: History and Scripture in the Thought of Hugh of St. Victor. Toronto: Pontifical Institute of Mediaeval Studies.

Harris, R. (2009) Medieval Jewish Biblical Exegesis. A History of Biblical Interpretation, vol. 2. A Hauser and D Watson (eds.), pp. 141-171. Grand Rapids: William B. Eerdman's Publishing Company.

Kamin, S. (1986). Rashi's Exegetical Categorization in Respect to the Distinction between Peshat and Derash [Hebrew]. Jerusalem: Magnes.

Klepper, D. (2007). The Insight of Unbelievers: Nicholas of Lyra and Christian Reading of Jewish Text in the Later Middle Ages. Philadelphia: University of Pennsylvania Press.

Klepper, D. (2008). Literal Versus Carnal: George of Siena's Christian Reading of Jewish Exegesis. Jewish Biblical Interpretation and Cultural Exchange, N Dohrman and D Stern eds, pp. 196-213. Philadelphia: University of Pennsylvania Press.

LaVere, S. (2009) Out of the Cloister: Scholastic Exegesis of the Song of Songs, 1100-1340". PhD Diss.., Northwestern University.

Levy, B. (1988) Rashi's Commentary on the Torah: A Survey of Recent Publications. Tradition 23(4), pp. $102-117$.

Minnis, A. and Scott, A.B. (1991). Medieval Literary Theory and Criticism c.1100-c.1375. Oxford: Clarendon Press.

Morey, J. (1993). Peter Comestor, Biblical Paraphrase, and the Medieval Popular Bible. Speculum, 68(1), pp. 6-35.

Schoenfeld, D. (2013). Isaac on Jewish and Christian Altars: Polemic and Exegesis in Rashi and in the Glossa Ordinaria. New York: Fordham University Press.

Schwartzfuchs, S. (2001). The Jews of France in the Middle Ages [Hebrew], Tel Aviv: Ha-ibuts ha-me\#x02BE; ad.

Signer, M. (1993). Peshat, Sensus Litteralis, and Sequential Narrative: Jewish Exegesis and the School of St. Victor in the Twelfth Century. In B Walfish (ed.), The Frank Talmage Memorial Volume, Haifa: Haifa University Press, pp. $203-216$. Smalley, B. (1935-6) Gilbertus Univeralis, Bishop of London (1128-34), and the Problem of the Glossa Ordinaria. Recherches de théologie ancienne et médiévale, 7, pp. 235-62 and 8 pp. 24-60.

Smalley, B. (1989). The Study of the Bible in the Middle Ages, Notre Dame: University of Notre Dame Press.

Smalley, B. (1984) Glossa Ordinaria. Theologische Realenzyklopadie, 13, pp. 452-457.

Smith, L. (2009) Glossa Ordinaria: The Making of a Medieval Bible Commentary. Leiden: Brill.

Swanson, J. (2001) The Glossa Ordinaria. In: The Medieval Theologians, Evans, G (ed), Oxford: Blackwell, pp. 156-167. Touitou, E. (2005) The Ever-renewing Literal Sense: Studies in Rashbam's Commentary on the Torah [Hebrew], Ramat Gan: Bar Ilan University Press, Ramat Gan.

Van Engen, J. (1983) Rupert of Deutz, Berkeley: University of California Press.

van Liere, F. (1995) Andrew of St Victor and the Gloss on Samuel and Kings. In: R Nip and van H Dijk (eds.), In Media Latinitas. A Collection of Essays to Mark the Occasion of the Retirement of L.J. Engels, pp. 249-53. Brepols: Instrumenta Patristica 28. Steenbrugge/Turnhout.

van Liere, F. (2005) Andrew of St. Victor, Jerome, and the Jews: Biblical Scholarship in the Twelfth-Century Renaissance. In: T Heffernan and T Burman, (eds.), Scripture and Pluralism: Reading the Bible in the Religiously Plural Worlds of the Middle Ages and Renaissance, pp. 59-75. Studies in the History of Christian Traditions 123. Leiden: Brill. 


\section{Author Query Form}

\section{Journal: Religion Compass}

\section{Article: rec 312090}

\section{Dear Author,}

During the copyediting of your paper, the following queries arose. Please respond to these by annotating your proofs with the necessary changes/additions.

- If you intend to annotate your proof electronically, please refer to the E-annotation guidelines.

- If you intend to annotate your proof by means of hard-copy mark-up, please refer to the proof mark-up symbols guidelines. If manually writing corrections on your proof and returning it by fax, do not write too close to the edge of the paper. Please remember that illegible mark-ups may delay publication.

Whether you opt for hard-copy or electronic annotation of your proofs, we recommend that you provide additional clarification of answers to queries by entering your answers on the query sheet, in addition to the text mark-up.

\begin{tabular}{|c|c|c|}
\hline Query No. & Query & Remark \\
\hline Q1 & $\begin{array}{l}\text { AUTHOR: "Smalley } 1964 \text { " is cited in text but not given in } \\
\text { the reference list. Please provide details in the list or delete } \\
\text { the citation from the text. }\end{array}$ & \\
\hline Q2 & $\begin{array}{l}\text { AUTHOR: The citation "Kamin 1984" (original) has been } \\
\text { changed to "Kamin, 1986". Please check if appropriate. }\end{array}$ & \\
\hline Q3 & $\begin{array}{l}\text { AUTHOR: The citation "Gow 1993" (original) has been } \\
\text { changed to "Gow, 1995". Please check if appropriate. }\end{array}$ & \\
\hline Q4 & AUTHOR: Year has been provided; please check if correct. & \\
\hline Q5 & $\begin{array}{l}\text { AUTHOR: Reference "Damian }(1989,1900,1992) \text { " is not } \\
\text { cited in the text. Please indicate where it should be cited; } \\
\text { or delete from the reference list. }\end{array}$ & \\
\hline Q6 & $\begin{array}{l}\text { AUTHOR: Reference "Evans (2001)" is not cited in the text. } \\
\text { Please indicate where it should be cited; or delete from the } \\
\text { reference list. }\end{array}$ & \\
\hline Q7 & $\begin{array}{l}\text { AUTHOR: Reference "Minnis \& Scott (1991)" is not cited } \\
\text { in the text. Please indicate where it should be cited; or } \\
\text { delete from the reference list. }\end{array}$ & \\
\hline
\end{tabular}




\begin{tabular}{|c|l|l|} 
Query No. & \multicolumn{1}{|c|}{ Query } & Remark \\
\hline Q8 & $\begin{array}{l}\text { AUTHOR: Reference "Schwartzfuchs (2001)" is not cited in } \\
\text { the text. Please indicate where it should be cited; or delete } \\
\text { from the reference list. }\end{array}$ & \\
\hline Q9 & $\begin{array}{l}\text { AUTHOR: Reference "Smalley (1935-6)" is not cited in the } \\
\text { text. Please indicate where it should be cited; or delete from } \\
\text { the reference list. }\end{array}$ & \\
\hline
\end{tabular}


Required software to e-Annotate PDFs: Adobe Acrobat Professional or Adobe Reader (version 7.0 or above). (Note that this document uses screenshots from Adobe Reader $\mathrm{X}$ )

The latest version of Acrobat Reader can be downloaded for free at: http://get.adobe.com/uk/reader/

Once you have Acrobat Reader open on your computer, click on the Comment tab at the right of the toolbar:

닙

This will open up a panel down the right side of the document. The majority of tools you will use for annotating your proof will be in the Annotations section, pictured opposite. We've picked out some of these tools below:

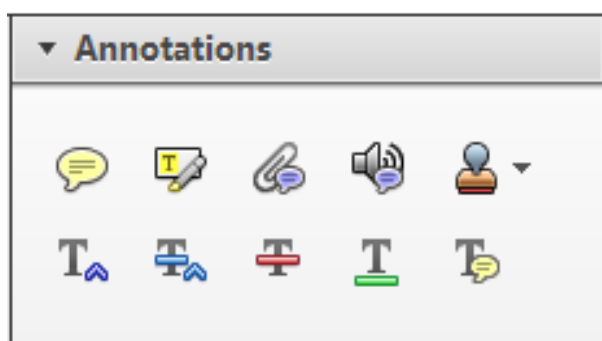

1. Replace (Ins) Tool - for replacing text.

Strikes a line through text and opens up a text box where replacement text can be entered.

How to use it

- Highlight a word or sentence.

- Click on the Replace (Ins) icon in the Annotations section.

- Type the replacement text into the blue box that appears.

Idard tramework for the analysis of $\mathrm{m}$ icy-Nevertheless, it also led to exog،

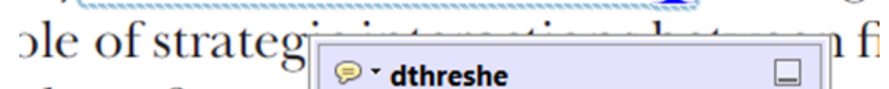
\begin{tabular}{l|l|l} 
aber of comp & 08/06/2011 15:58:17 & 0
\end{tabular} is that the $\mathrm{s} 1 \overline{\text {, which led }}$ of nain compo: be level, are exc nc

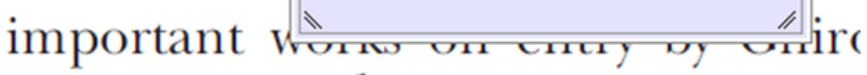
M heneferth) ${ }^{1}$ we anen the "hlarl $\mathrm{h}$

3. Add note to text Tool - for highlighting a section to be changed to bold or italic.

T Highlights text in yellow and opens up a text box where comments can be entered.

How to use it

- Highlight the relevant section of text.

- Click on the Add note to text icon in the Annotations section.

- Type instruction on what should be changed regarding the text into the yellow box that appears.

namic responses of mark ups ent with the VAR evidence

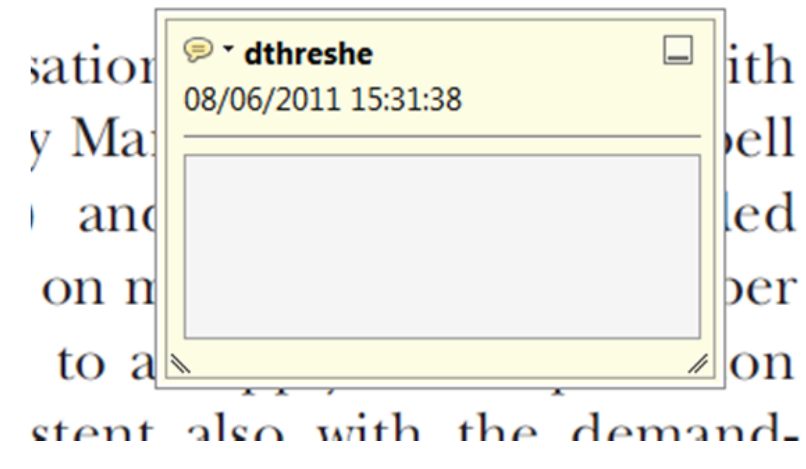

2. Strikethrough (Del) Tool - for deleting text.

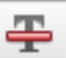

Strikes a red line through text that is to be deleted.

How to use it

- Highlight a word or sentence.

- Click on the Strikethrough (Del) icon in the Annotations section.

there is no room tor extra prohts al s ups are zero and the number of ret) values are not determined by Blanchard and Kiyotaki (1987), sfect competition in general equilil ts of aggregate demand and supply lassical framework assuming monol sen an evorenous number of firms

4. Add sticky note Tool - for making notes at specific points in the text.

Marks a point in the proof where a comment needs to be highlighted.

How to use it

- Click on the Add sticky note icon in the Annotations section.

- Click at the point in the proof where the comment should be inserted.

- Type the comment into the yellow box that appears.

iaisu airu suppiy sisuks. hivsl ui

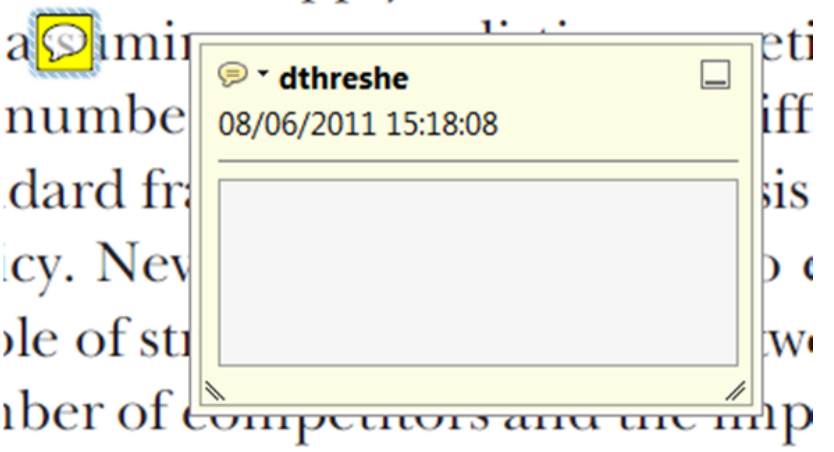

is that the structure of the sectc. 
5. Attach File Tool - for inserting large amounts of text or replacement figures.

Inserts an icon linking to the attached file in the appropriate pace in the text.

How to use it

- $\quad$ Click on the Attach File icon in the Annotations section.

- Click on the proof to where you'd like the attached file to be linked.

- Select the file to be attached from your computer or network.

- Select the colour and type of icon that will appear in the proof. Click OK.

E N D

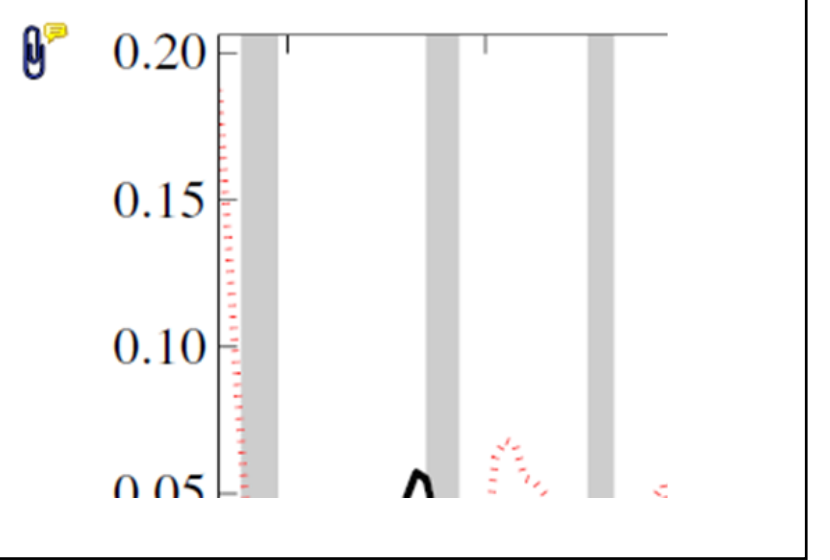

6. Add stamp Tool - for approving a proof if no corrections are required.

- Inserts a selected stamp onto an appropriate place in the proof.

\section{How to use it}

- $\quad$ Click on the Add stamp icon in the Annotations section.

- Select the stamp you want to use. (The Approved stamp is usually available directly in the menu that appears).

- Click on the proof where you'd like the stamp to appear. (Where a proof is to be approved as it is, this would normally be on the first page).

)t the Dusiness cycie, starting with the on perfect competition, constant ret

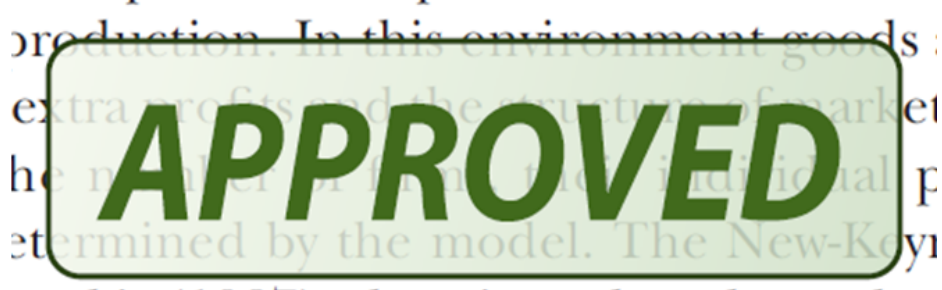
otaki (1987), has introduced produc general equilibrium models with nomin:

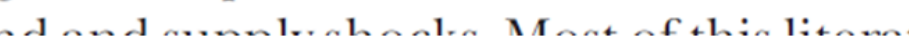

- Drawing Markups

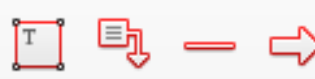

$0 \bigcirc \sqrt{6} \otimes$

\section{How to use it}

- Click on one of the shapes in the Drawing Markups section.

- Click on the proof at the relevant point and draw the selected shape with the cursor.

- To add a comment to the drawn shape, move the cursor over the shape until an arrowhead appears.

- Double click on the shape and type any text in the red box that appears.
7. Drawing Markups Tools - for drawing shapes, lines and freeform annotations on proofs and commenting on these marks.

Allows shapes, lines and freeform annotations to be drawn on proofs and for comment to be made on these marks.

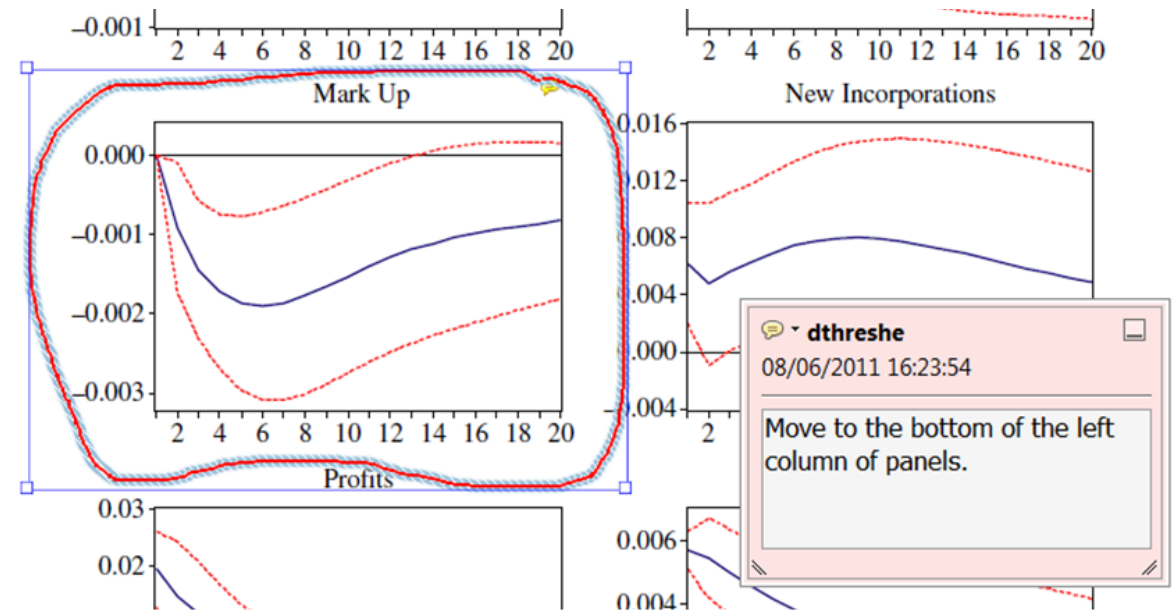

For further information on how to annotate proofs, click on the Help menu to reveal a list of further options:

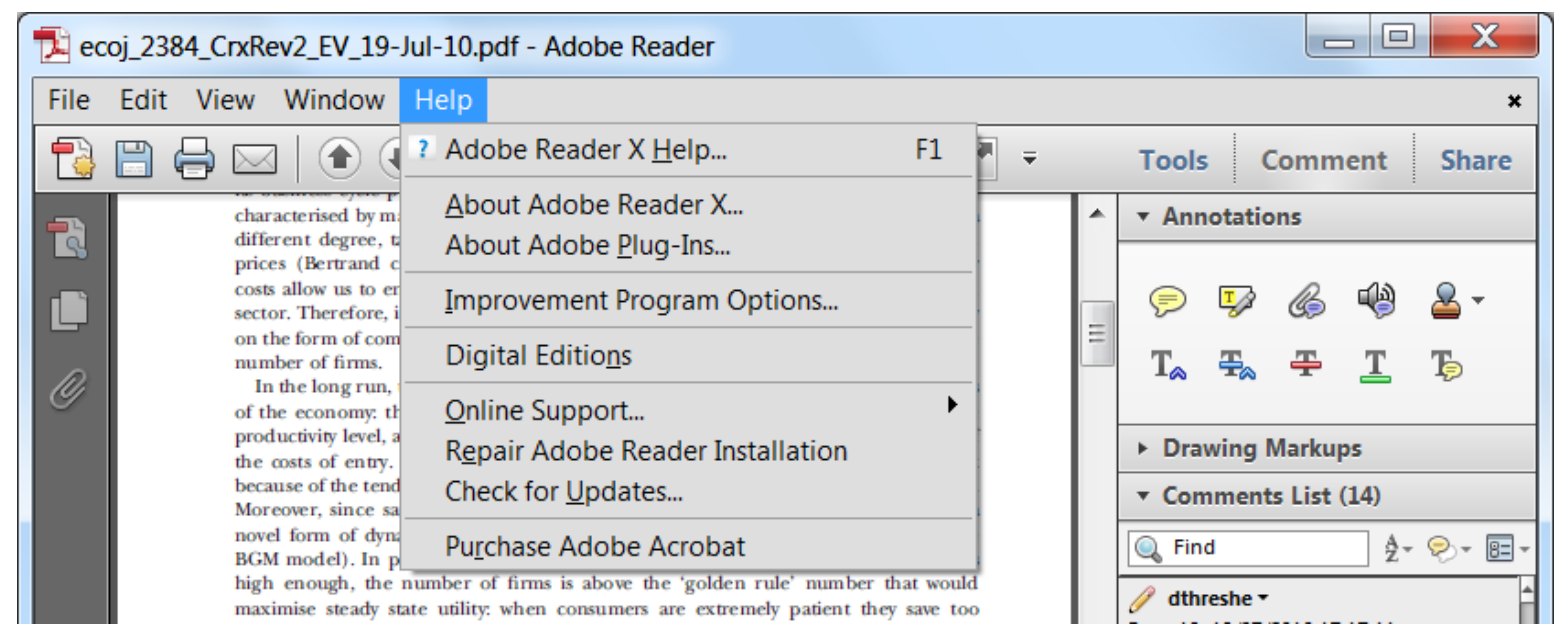

